\title{
Influence of Plant Growth Regulators on Physiological Traits under Salinity Stress in Constrasting Rice Varieties (Oryza sativa L.)
}

\author{
E. Kanmani, V. Ravichandran, R. Sivakumar, A. Senthil, \\ K. Krishna Surendar and P. Boominathan* \\ Department of Crop Physiology, Tamil Nadu Agricultural University, Coimbatore-3, India \\ *Corresponding author
}

\section{A B S T R A C T}

\begin{tabular}{|l|}
\hline Ke y w o r d s \\
Salinity, Rice, \\
Photosynthetic \\
Rate, Chlorophyll \\
Index, Chlorophyll \\
Fluorescence. \\
\hline Article Info \\
\hline $\begin{array}{l}\text { Accepted: } \\
\text { 17 April } 2017 \\
\text { Available Online: } \\
\text { 10 May } 2017\end{array}$ \\
\hline \hline
\end{tabular}

\section{Introduction}

Salinity is becoming a big threat for agricultural crops and is common in arid and semi-arid regions. It is the major limiting factor for enhancing the growth and productivity of agricultural crops. The presence of salts in the soil and their effects on the plant physiological mechanisms was major restrictive factor for agricultural productivity (Qadir et al., 2008). Salinity stress significantly reduced many physiological characters such as photosynthetic efficiency and chlorophyll stability index as well as sugar contents (Jamil et al., 2007). Chlorophylls are the green pigment performing the most important role in photochemical reactions during photosynthesis. The level and state of chlorophyll pigments in the leaf tissue are important factors which determine the overall photosynthetic efficiency of a plant. Sultana (1999) reported that chlorophyll a fluorescence including Fv/Fm, ФPSII, qP and 
NPQ is affected in salt stress and mainly PSII is damaged in the plants (Kalaji and Guo, 2008). Plants also show the high chlorophyll degradation symptom, chlorosis as a common morphological and physiological characteristic in response to the salt stress (Harinasut et al., 2000). Exogenous application of PGRs, gibberellins (Afzal et al., 2005), cytokinins (Gul et al., 2000) produces some benefit in alleviating the adverse effects of salt stress and also improves germination, growth and development seed yield and quality (Egamberdieva, 2009). Based on information available on stress alleviation, the study was taken up with four PGRs such as brassinosteriods, gibberellic acid, salicylic acid and kinetin which are relevant in relation to stress tolerance especially salinity.

\section{Materials and Methods}

The pot culture experiment was carried out using two rice varieties namely pokkali and CO51 with foliar application of different plant growth regulators at varied concentrations under salinity conditions. CO51 is short duration and high yielding semi dwarf rice variety while pokkali is a well-known salt tolerant variety grown in coastal areas of Kerala. The plant growth regulators were applied at tillering stage (45 DAS) for amelioration of salinity with $160 \mathrm{mM} \mathrm{NaCl}$.

The water sprayed plants were taken as control and the plants without salt stress are considered as absolute control. These experiments were carried out in the Department of Crop Physiology, Tamil Nadu Agricultural University, Coimbatore. Physiological parameters associated with salinty stress tolerance such as photosynthesis rate, transpiration rate, chlorophyll fluorescence and chlorophyll meter readings were recorded. The photosynthetic and transpiration rates were measured using portable photosynthesis system (LI-6400XT, Licor Inc, Nebraska, USA) and expressed as $\mu \mathrm{mol} \mathrm{CO}_{2} \mathrm{~m}^{-2} \mathrm{~s}^{-1}$ and $\mathrm{mmol} \mathrm{H}_{2} \mathrm{O} \mathrm{m} \mathrm{m}^{-2} \mathrm{~s}^{-1}$ respectively. The amount of chlorophyll present in leaves was measured by non-destructive method using chlorophyll meter (CCM300, Delta-T Devices, UK) as suggested by Peng (1996) and expressed as chlorophyll meter readings. Chlorophyll fluorescence measurements were recorded using waltz, Germany and expressed as $\mathrm{F}_{\mathrm{v}} / \mathrm{F}_{\mathrm{m}}$. Statistical analysis of the data with three replicates was performed using ANOVA and compared with least significant differences (LSD) at the $5 \%$ level, according to the procedure of Gomez and Gomez (1984).

\section{Results and Discussion}

Abiotic stress has been considered as major limiting factor and it is estimated that more than half of the yield potential of major crops is usually lost due to unfavorable environments such as drought or high salinity (Cortina and Culianez-Macia, 2005). This can be recovered to a certain extent with the applications of plant growth regulators (PGRs) that play an important role in several physiological and molecular processes of plants. In addition, PGRs used as potential tools to increase defense mechanisms against stress conditions (Nair et al., 2009).

Different approaches were adopted to mitigate the effect of salinity and one of the options was to use the plant growth regulators (Ashraf and Foolad, 2007). Here, we attempted to study the influence of foliar applied plant growth regulators in rice under salt stress with idea of developing management techniques for mitigation of salinity stress and the effects were quantified in terms of alteration in physiological traits mainly gas exchange and chlorophyll fluorescence parameters. 
Effect of plant growth regulators on photosynthesis and transpiration under salt stress

Photosynthesis is the primary determinant of plant growth and yield. Current study showed that salt stress caused significant reduction in photosynthetic rate (Table 1). Among the PGRs, application of $1 \mathrm{ppm}$ of Brassinolide $\left(\mathrm{T}_{3}\right)$ resulted in higher photosynthetic rate while the lower value recorded in $150 \mathrm{ppm}$ of salicylic acid $\left(\mathrm{T}_{4}\right)$ under $160 \mathrm{mM} \mathrm{NaCl}$ irrespective of varieties and stages.

Salt accumulation in the expanding leaves has been correlated with photosynthetic decline with ultra-structural and metabolic damages and sequential death of leaves. Under saline conditions, reduction in photosynthesis can also be attributed to changes in chlorophyll fluorescence, photoinhibition of photosystem II (PS-II), conformational changes in membrane bound ATPase enzyme complex as well as decrease in both concentration and activity of Rubisco enzyme (Lawlor, 2002). The destruction of chloroplast structure by $\mathrm{NaCl}$ toxicity may lead to stomatal closure caused by oxidative stress (Ashraf, 2009). High concentrations of injurious ions, such as $\mathrm{Na}^{+}$and $\mathrm{Cl}^{-}$, which accumulate in the chloroplasts under salinity stress, are known to damage thylakoid membranes (Wu and Zou, 2009 and Omoto et al., 2010).

Among the four hormones studied, foliar application of $1 \mathrm{ppm}$ of brassinolide was found to be effective in enhancing photosynthetic rate under salinity stress and interestingly, the response was similar in both varieties.

This might be due to increase in light saturated net $\mathrm{CO}_{2}$ assimilation rate accompanied by the increase in the maximum carboxylation rate of Rubisco and a higher quantum yield of PSII electron transport (Yu et al., 2004). The findings of present study is in accordance with the findings of Braun and Wild (1984) in wheat and Mustard. Transpiration rate determines the significance of various physiological processes along with their impact on biomass production and yield. Significant reduction in transpiration rate was observed in salt stress conditions. Further, lower transpiration rate recorded in salinity tolerant variety (pokkali) compared to CO 51 implying role of transpiration in maintaining the water status of plants. In the present study, significant variation between the two different varieties was observed under saline condition with transpiration rate was found higher in CO51 (Table 1). The results on transpiration rate revealed that $\mathrm{CO} 51$ showed the higher value $(5.0,2.5)$ in salt stress both the stages compared to pokkali $(1.4,0.5)$. Among the treatments, 20 ppm of kinetin $\left(\mathrm{T}_{5}\right)$ showed the highest transpiration rate in both the varieties. Application of kinetin, might improve the salt tolerance of rice variety by reducing the uptake of $\mathrm{Na}^{+}$ion and improve the capacity to absorb water by increasing in osmotic component of soil water potential (Ramadan et al., 2004).

Effect of plant growth regulators on chlorophyll fluorescence and chlorophyll index

The Fv/Fm ratio measures the efficiency of excitation energy captured by open PSII reaction centres representing the maximum capacity of light-dependent charge separation (Krause et al., 1991). Current study showed that salt stress caused significant reduction in chlorophyll fluorescence compared to control conditions (Table 2).

Among the PGRs, application of $1 \mathrm{ppm}$ brassinolide $\left(\mathrm{T}_{3}\right)$ resulted in higher chlorophyll fluorescence in both varieties indicating that response to plant growth regulators is similar irrespective of their nature of tolerance to salinity. 
Table.1 Effect of salt stress and plant growth regulators on photosynthetic rate ( $\mu$ mol CO2 m-2 s-1) and Transpiration rate (mmol H2 O m-2 s-1)

\begin{tabular}{|c|c|c|c|c|c|c|c|c|c|c|c|c|}
\hline \multirow{3}{*}{ Treatments } & \multicolumn{6}{|c|}{ Photosynthetic rate $\left(\mu \mathrm{mol} \mathrm{CO}_{2} \mathrm{~m}^{-2} \mathrm{~s}^{-1}\right)$} & \multicolumn{6}{|c|}{ Transpiration rate $\left(\mathrm{mmol} \mathrm{H}_{2} \mathrm{O} \mathrm{m}^{-2} \mathrm{~s}^{-1}\right)$} \\
\hline & \multicolumn{3}{|c|}{ Tillering stage } & \multicolumn{3}{|c|}{ Flowering stage } & \multicolumn{3}{|c|}{ Tillering stage } & \multicolumn{3}{|c|}{ Flowering stage } \\
\hline & $\mathbf{V}_{1}$ & $\mathbf{V}_{2}$ & Mean & $\mathbf{V}_{1}$ & $\mathbf{V}_{2}$ & Mean & $\mathbf{V}_{1}$ & $\mathbf{V}_{2}$ & Mean & $\mathbf{V}_{1}$ & $\mathbf{V}_{2}$ & Mean \\
\hline $\mathrm{T}_{1}$-Absolute control & 34.2 & 32.5 & 33.4 & 20.2 & 33.6 & 26.9 & 6.7 & 9.2 & 7.9 & 1.4 & 4.5 & 2.9 \\
\hline $\mathrm{T}_{2}$-Control(water spray) & 11.8 & 18.8 & 15.3 & 6.7 & 20.6 & 13.6 & 1.4 & 5.0 & 3.2 & 0.5 & 2.5 & 1.4 \\
\hline $\mathrm{T}_{3}$-Brassinolide@1ppm & 33.2 & 30.1 & 31.6 & 16.9 & 27.5 & 20.9 & 3.3 & 4.8 & 4.0 & 1.0 & 3.3 & 2.5 \\
\hline $\mathrm{T}_{4}$-Salicylic acid@150ppm & 26.3 & 27.5 & 26.9 & 14.8 & 24.7 & 19.7 & 3.7 & 5.3 & 4.5 & 1.1 & 2.7 & 1.9 \\
\hline $\mathrm{T}_{5}$-Kinetin@20ppm & 26.3 & 24.5 & 25.4 & 12.2 & 22.3 & 19.8 & 4.9 & 6.0 & 5.5 & 1.7 & 3.4 & 2.2 \\
\hline $\mathrm{T}_{6}-\mathrm{MCP} @ 1 \mathrm{ppm}$ & 32.7 & 27.7 & 30.2 & 14.0 & 25.5 & 18.2 & 4.8 & 5.2 & 5.0 & 1.4 & 3.3 & 2.3 \\
\hline $\mathrm{T}_{7}$-Gibberllic acid@50ppm & 30.7 & 24.7 & 30.3 & 16.0 & 20.4 & 18.1 & 3.4 & 5.0 & 4.2 & 1.5 & 3.3 & 2.5 \\
\hline Mean & 27.8 & 26.5 & 27.2 & 14.3 & 25.0 & 19.6 & 4.0 & 5.8 & 4.9 & 1.2 & 3.4 & 2.3 \\
\hline Factors & $\mathbf{V}$ & $\mathbf{T}$ & $\mathbf{V} \mathbf{X} \mathbf{T}$ & $\mathbf{V}$ & $\mathbf{T}$ & $\mathbf{V} \mathbf{X} \mathbf{T}$ & $\mathbf{V}$ & $\mathbf{T}$ & $\mathbf{V} \mathbf{X} \mathbf{T}$ & $\mathbf{V}$ & $\mathbf{T}$ & $\mathbf{V} \mathbf{X} \mathbf{T}$ \\
\hline S. Ed & 0.02 & $\mathbf{0 . 0 3}$ & 0.04 & 0.005 & 0.009 & 0.01 & 0.05 & 0.09 & 0.12 & 0.001 & 0.003 & 0.005 \\
\hline $\mathrm{CD}(\mathrm{P}=\mathbf{0 . 0 5})$ & $\mathbf{0 . 0 3} * *$ & $0.06 * *$ & $0.12 * *$ & $0.01 * *$ & $0.19 * *$ & $0.03 * *$ & $0.09 * *$ & $0.18 * *$ & $0.25 * *$ & $0.004 * *$ & $0.006 * *$ & $0.009 * *$ \\
\hline
\end{tabular}

$\mathrm{V}_{1}-$ Pokkali $\mathrm{V}_{2}-\mathrm{CO} 51$ 
Table.2 Effect of salt stress and plant growth regulators on chlorophyll fluorescence (Fv/Fm) and chlorophyll index

\begin{tabular}{|c|c|c|c|c|c|c|c|c|c|c|c|c|}
\hline \multirow{3}{*}{ Treatments } & \multicolumn{6}{|c|}{ Chlorophyll fluorescence $\left(F_{v} / F_{m}\right)$} & \multicolumn{6}{|c|}{ Chlorophyll meter readings } \\
\hline & \multicolumn{3}{|c|}{ Tillering stage } & \multicolumn{3}{|c|}{ Flowering stage } & \multicolumn{3}{|c|}{ Tillering stage } & \multicolumn{3}{|c|}{ Flowering stage } \\
\hline & $\mathbf{V}_{1}$ & $\mathbf{V}_{2}$ & Mean & $\mathbf{V}_{1}$ & $\mathbf{V}_{2}$ & Mean & $\mathbf{V}_{1}$ & $\mathbf{V}_{2}$ & Mean & $\mathbf{V}_{1}$ & $\mathbf{V}_{2}$ & Mean \\
\hline $\mathrm{T}_{1}$-Absolute control & 0.7 & 0.7 & 0.7 & 0.5 & 0.6 & 0.6 & 533 & 423 & 478 & 462 & 380 & 423.9 \\
\hline $\mathrm{T}_{2}$-Control(water spray) & 0.5 & 0.6 & 0.6 & 0.4 & 0.5 & 0.5 & 279 & 409 & 343 & 276 & 232 & 254.6 \\
\hline $\mathrm{T}_{3}$-Brassinolide@1ppm & 0.8 & 0.7 & 0.7 & 0.7 & 0.7 & 0.7 & 383 & 445 & 413 & 305 & 407 & 356.4 \\
\hline $\mathrm{T}_{4}$-Salicylic acid@150ppm & 0.5 & 0.6 & 0.5 & 0.6 & 0.6 & 0.6 & 380 & 433 & 407 & 336 & 438 & 427.6 \\
\hline $\mathrm{T}_{5}$-Kinetin@20ppm & 0.5 & 0.6 & 0.6 & 0.6 & 0.6 & 0.6 & 412 & 329 & 388 & 411 & 433 & 401.2 \\
\hline $\mathrm{T}_{6}-\mathrm{MCP} @ 1 \mathrm{ppm}$ & 0.5 & 0.5 & 0.5 & 0.5 & 0.6 & 0.6 & 441 & 512 & 476 & 411 & 451 & 431.5 \\
\hline $\mathrm{T}_{7}$-Gibberllic acid@50ppm & 0.6 & 0.5 & 0.5 & 0.5 & 0.6 & 0.6 & 449 & 537 & 474 & 434 & 466 & 432.4 \\
\hline Mean & 0.5 & 0.6 & 0.6 & 0.5 & 0.6 & 0.5 & 411 & 441 & 426 & 377 & 401 & 389.6 \\
\hline Factors & $\mathbf{V}$ & $\mathbf{T}$ & $\mathbf{V} \times \mathbf{T}$ & $\mathbf{V}$ & $\mathbf{T}$ & $\mathbf{V} \times \mathbf{T}$ & V & $\mathbf{T}$ & $\mathbf{V} \times \mathbf{T}$ & $\mathbf{V}$ & $\mathbf{T}$ & $\mathrm{V} \times \mathrm{T}$ \\
\hline S. Ed & 0.009 & 0.028 & 0.02 & 0.02 & 0 & 0.06 & 17.4 & 32.6 & 46.2 & 3.01 & 5.6 & 7.9 \\
\hline $\mathrm{CD}(\mathrm{P}=0.05)$ & $0.02 * *$ & $0.03 * *$ & $0.05 * *$ & $0.05 *$ & NS & NS & NS & $66.0 *$ & $93.2 *$ & $6.10 * *$ & $11.4 * *$ & $16.1^{* *}$ \\
\hline
\end{tabular}


Increased $\mathrm{CO}_{2}$ assimilation rate in brassinolide treated leaves was accompanied by a higher quantum yield of PSII electron transport, mainly due to a significant increase in the photochemical quenching and unchanged efficiency of energy capture by open PSII reaction centers.

Moreover, brassinolide had a positive effect on the activation of Rubisco based on increased maximum Rubisco carboxylation rates, total Rubisco activity and initial Rubisco activity induced by an enhanced expression of genes encoding other Calvin cycle genes. BRs treatment might also play a positive role in RuBP regeneration, thereby increasing maximum carboxylation rate of Rubisco (Hayat et al., 2010).

Chlorophyll index using chlorophyll meter (CCM) permits a rapid and non-destructive determination of leaf chlorophyll content by measuring leaf transmittance. The measurement of chlorophyll index value, which is very simple and rapid, has been applied in rice as an index for salt tolerance screening (Hussain et al., 2000; Mohan et al., 2000). The chlorophyll index value decreased upon increases in the duration of salinity. Hernandez et al., (2000) observed that salinity can cause leaf injury manifested by a reduction in chlorophyll content.

The higher values of chlorophyll had attributed to an increased photosynthetic rate, resulting in higher dry matter production. In the present study, significant variation between the two different varieties was observed under salt stress condition with chlorophyll index was found to be higher in CO51 in tillering stage (409) while pokkali registered higher value in flowering stage (276) (Table 2). The results indicate that the tolerance variety pokkali was able to maintain the chlorophyll content during flowering, the trait necessary for synthesis of photosynthates for grain filling. Among the treatments, 50 ppm gibberellic acid $\left(\mathrm{T}_{7}\right)$ showed the higher chlorophyll index in both the varieties. $\mathrm{GA}_{3}$ foliar application could effectively compensate such depression by preventing the chlorophyll breakdown under salinity. It is also due to retention of chlorophyll and delay of senescence. This result is corroborating with result of Misratia et al., (2013) in rice and Rama et al., (2014) in maize.

In conclusion, in recent years the growth rates of world agricultural production and crop yields have been reduced due to increase in saline condition in the field. Of the various management options available, mitigation through plant growth regulators is promising in terms reducing yield reduction under stress. The pot culture studies revealed that salinity adversely affected the gas exchange parameters, chlorophyll fluoresce and chlorophyll index which could be improved through application of application of plant growth regulators. It is also interesting to note that application of plant growth regulators was not showed not much varietal differences for responses as measured by physiological traits. Therefore, these results have practical field applications in terms of improving physiological traits thereby enhancing the yield under salt stress. Further studies would be required to identify the alteration in gene expression in PGR applied plants.

\section{References}

Afzal, I., Basra, S. and Iqbal, A. 2005. The effect of seed soaking with plant growth regulators on seedling vigor of wheat under salinity stress. J. Stress Physiol. Biochem., 1: 6-14.

Ashraf, M. and Foolad, M.R. 2007. Roles of glycinebetaine and proline in improving plant abiotic stress resistance. Environ. Exp. Bot., 59: 206-16. 
Ashraf, M. 2009. Biotechnological approach of improving plant salt tolerance using antioxidants as markers. Biotech. Adv., 27: 84-93.

Braun, P. and Wild, A. 1984. The influence of brassinosteroid on growth and parameters of photosynthesis of wheat and mustard plants. J. Plant Physiol., 116: 189-196.

Cortina, C. and Culiáñez-Macià, F.A. 2005. Tomato abiotic stress enhanced tolerance by trehalose biosynthesis. Plant Sci., 169(1): 75-82.

Egamberdieva. D. 2009. Alleviation of salt stress by plant growth regulators and IAA producing bacteria in wheat. Acta Physiol. Plant, 31: 861-864.

Gomez, K.A. and Gomez, A.A. 1984. Statistical procedures for agricultural research. $\left(2^{\text {nd }}\right.$ Ed.) John Wiley and sons, New York, USA. p. 680.

Gopalachari, N.C. 1963. Changes in activities of certain oxidizing enzymes during germination and seedling development of (Phaseolus mungo L. and Sorghum vulgare..L). Ind. J. Exp. Bio., 1: 98-100.

Gul, B., Khan, K.M. and Weber. D.J. 2000. Alleviation salinity and dark enforced dormancy in Allenrolfea occidentalis seeds under various thermoperiods. Aust. J. Bot., 48: 745-752.

Harinasut, P., Srisunak, S. Pitukchaisopol, S. and Charoensataporn, R. 2000. Mechanisms of adaptation to increasing salinity of mulberry: proline content and ascorbate peroxidase activity in leaves of multiple shoots. Sci. Asia, 26: 20711.

Hayat, S., Hasan, S.A. Yusuf, M. Hayat, Q. and Ahmad, A. 2010. Effect of 28homobrassinolide on photosynthesis, fluorescence and antioxidant system in the presence or absence of salinity and temperature in Vigna radiata. Environ. Exp. Bot., 69: 105-112.

Hernandez, J.A., Olmos, E. Corpas, F.J.
Sevilla, F. and Del Rio, L.A. 1995. Saltinduced oxidative stress in chloroplasts of pea plants. Plant Sci., 105: 151-167.

Hussain, F., Bronson, K.F., Singh, Y., Singh, B. and Peng, S. 2000. Use of chlorophyll meter sufficiency indices for nitrogen management of irrigated rice in Asia. Agron. J., 92: 875-879.

Jamil, M. and Rha, E.S. 2007. Response of transgenic rice at germination and early seedling growth under salt stress. Pakistan J. Biol. Sci., 10: 4303-4306.

Kalaji, M.H. and Guo, P. 2008. Chlorophyll fluorescence: a useful tool in barley plant breeding programs. In: A. Sanchez and S.J. Gutierrez (Eds). Photochem. Res. Progress. Nova Publ. NY., USA, pp- 439-463.

Krause, G.H. and Weis, E. 1991. Chlorophyll fluorescence and photosynthesis. The basics. - Annu. Rev. Plant Physiol. Plant mol. Biol., 42: 313-349.

Lawlor, D.W. 2002. Limitation to photosynthesis in water stressed leaves: stomata vs. metabolism and the role of ATP, Annals. Bot., 89: 871-885.

Misratia, A.K. and Niragidave, N. 2013. Impact of soil salinity and erosion and its overall impact on India. Inter. J. Innovative Res. Eng. Sci., 3(2): 12-17.

Mohan, M., Narayanan, M. and Ibrahim, S.M. 2000. Chlorophyll Stability Index 1027(CSI): Its impact on salt tolerance in rice. Int. Rice Res. Notes, 25: 38-39.

Nair, V.D., Gopi, R. Mohan kumar, M. Kavina, J. and Panneerselvam, R. 2012. Effect of triadimefon: a triazole fungicide on oxidative stress defense system and eugenol content in Ocimum tenuiflorum (L.). Acta Physiol Plant, 34: 599-605.

Omoto, E., Taniguchi, M. and Miyake, H. 2010. Effects of salinity stress on the structure of bundle sheath and mesophyll chloroplasts in NAD- malic enzyme and PCK type $\mathrm{C}_{4}$ plants. - Plant 
Prod. Sci., 13: 169-176.

Peng, S., Garcia, F.V. Laza, R.C. Sanico, A.L. Visperas, R.M. and Cassman, K.G. 1996. Increased N-use efficiency using a chlorophyll meter on highyielding irrigated rice. Field Crops Res., 47: 243-252.

Qadir, M., Tubeileh, A. Akhtar, J. and Khan, M.A. 2008. Productivity enhancement of salt-affected environments through crop diversification. Land Degradation and Develop., 19: 429-453.

Rama, D., Lakkineni, V.K. Bose, P. Ali, S. and Annapurna, K. 2013. Mitigation of salt stress in wheat seedlings by halo tolerant bacteria isolated from saline habitats. Springer Plus, 2: 6.

Ramadan, T. and Flowers, T.J. 1994. Effects of salinity and benzyl adenine on development and function of microhairs of Zea mays ( L.). Planta, 219: 639-648.

Sultana, N., Ikeda, T. and Itoh, R. 1999. Effect of $\mathrm{NaCl}$ Salinity on Photosynthesis and Dry Matter Accumulation in Developing Rice Grains. Environ. Exp. Bot., 42: 211220.

Wu, Q.S. and Zou, N.Y. 2009. Adaptive responses of birch-leaved pear (Pyrus betulaefolia) seedlings to salinity stress. Not. Bot. Hort. Agrobot. Cluj., 37: 133138.

Yu, J.Q., Huang, L.F Hu, W.H. Zhou, Y.H. Mao, W.H. and Ye, S.F. 2004. A role of brassinosteriods in the regulation of photosynthesis in Cucumis sativus. J. Exp. Bot., 55: 1135-1143.

\section{How to cite this article:}

Kanmani, E., V. Ravichandran, R. Sivakumar, A. Senthil, K. Krishna Surendar and Boominathan, P. 2017. Influence of Plant Growth Regulators on Physiological Traits under Salinity Stress in Constrasting Rice Varieties (Oryza sativa L.). Int.J.Curr.Microbiol.App.Sci. 6(5): 1654-1661. doi: https://doi.org/10.20546/ijcmas.2017.605.180 